\title{
CCN predictions using simplified assumptions of organic aerosol composition and mixing state: a synthesis from six different locations
}

\author{
B. Ervens ${ }^{1,2}$, M. J. Cubison ${ }^{1}$, E. Andrews ${ }^{1,2}$, G. Feingold ${ }^{2}$, J. A. Ogren ${ }^{2}$, J. L. Jimenez ${ }^{1,3}$, P. K. Quinn ${ }^{4}$, T. S. Bates ${ }^{4}$, \\ J. Wang ${ }^{5}$, Q. Zhang ${ }^{6}$, H. Coe ${ }^{7}$, M. Flynn ${ }^{7}$, and J. D. Allan ${ }^{8}$ \\ ${ }^{1}$ Cooperative Institute for Research in the Environmental Sciences (CIRES), University of Colorado, Boulder, CO, USA \\ ${ }^{2}$ NOAA Earth System Research Laboratory, Boulder, CO, USA \\ ${ }^{3}$ Department of Chemistry and Biochemistry, University of Colorado, Boulder, CO, USA \\ ${ }^{4}$ NOAA Pacific Marine Environmental Laboratory, Seattle, WA, USA \\ ${ }^{5}$ Brookhaven National Laboratory, 75 Rutherford Drive, Upton, NY, USA \\ ${ }^{6}$ Department of Environmental Toxicology, University of California, Davis, CA, USA \\ ${ }^{7}$ School of Earth, Atmospheric and Environmental Science, The University of Manchester, UK \\ ${ }^{8}$ National Centre for Atmospheric Science, School of Earth, Atmospheric and Environmental Sciences, The University of \\ Manchester, Manchester, UK
}

Received: 9 September 2009 - Published in Atmos. Chem. Phys. Discuss.: 9 October 2009

Revised: 11 May 2010 - Accepted: 16 May 2010 - Published: 26 May 2010

\begin{abstract}
An accurate but simple quantification of the fraction of aerosol particles that can act as cloud condensation nuclei $(\mathrm{CCN})$ is needed for implementation in large-scale models. Data on aerosol size distribution, chemical composition, and CCN concentration from six different locations have been analyzed to explore the extent to which simple assumptions of composition and mixing state of the organic fraction can reproduce measured CCN number concentrations.

Fresher pollution aerosol as encountered in Riverside, CA, and the ship channel in Houston, TX, cannot be represented without knowledge of more complex (size-resolved) composition. For aerosol that has experienced processing (Mexico City, Holme Moss (UK), Point Reyes (CA), and Chebogue Point (Canada)), CCN can be predicted within a factor of two assuming either externally or internally mixed soluble organics although these simplified compositions/mixing states might not represent the actual properties of ambient aerosol populations, in agreement with many previous CCN studies in the literature. Under typical conditions, a factor of two uncertainty in $\mathrm{CCN}$ concentration due to composition assump-
\end{abstract}

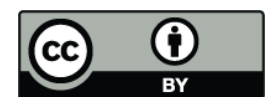

Correspondence to: $\mathrm{B}$. Ervens (barbara.ervens@noaa.gov) tions translates to an uncertainty of $\sim 15 \%$ in cloud drop concentration, which might be adequate for large-scale models given the much larger uncertainty in cloudiness.

\section{Introduction}

Aerosol-cloud interactions represent one of the largest uncertainties in estimating the effects of aerosol on radiative forcing. One key parameter for this estimate is to determine what fraction of aerosol particles can act as cloud condensation nuclei $(\mathrm{CCN})$ and form cloud droplets. The propensity of a particle to form $\mathrm{CCN}$ depends on its size, chemical composition and the supersaturation to which it is exposed. Whereas size distributions are routinely measured in field experiments, the full characterization of the chemical composition presents a major challenge since, in particular, the organic fraction of particles can be composed of hundreds of compounds with different physicochemical properties (e.g., surface tension, solubility, degree of dissociation, molecular weight). In laboratory and theoretical studies, it has been shown that these properties can enhance or reduce the $\mathrm{CCN}$ ability of organic particles as compared to better-characterized inorganic particles (Corrigan and Novakov, 1999; Cruz and Pandis, 2000). For ambient particle populations, it is not feasible to consider

Published by Copernicus Publications on behalf of the European Geosciences Union. 
all individual compounds due to the far from complete characterization of the organic fraction at the molecular level, and the computational burden the description of hundreds of individual compounds represents in models.

There is no consensus about the importance of detailed knowledge of aerosol composition (including mixing state) in studies that compare measured and modeled CCN number concentrations ("CCN closure"). Some studies report that this information is of minor importance for successful $\mathrm{CCN}$ closure and that aerosol size distribution largely determines the fraction that can be activated at a given supersaturation (Conant et al., 2004; Dusek et al., 2006; Ervens et al., 2007). Other studies show that measured CCN number concentrations can only be reproduced if detailed organic properties/mixing state are taken into account (Mircea et al., 2005; Stroud et al., 2007; Cubison et al., 2008).

With increasing distance from emission sources, particles become mixed by both physical processes (e.g., coagulation or condensation of semivolatile and low-volatility organic and inorganic compounds) or chemical processes (e.g., oxidation of primary (organic) species yielding more watersoluble products, and particle-phase reactions). These ageing processes lead to growth of the particles, i.e. an increase in their CCN ability at a given supersaturation, and/or to an increase in the hygroscopic fraction and, thus, to a reduction in the size threshold ("critical diameter") above which particles can be activated at a given supersaturation (Petters et al., 2006; Furutani et al., 2008).

Most CCN studies published to date have been limited to sampling at one site and, thus, it is not clear how to generalize their conclusions about $\mathrm{CCN}$ activation as a function of aerosol mixing state and organic solubility. In a global model study, it has been shown that different assumptions on mixing state and organic solubility might significantly affect CCN number concentrations (Pierce et al., 2007). The motivation of the current study is to explore the applicability of these simplifying composition/mixing state assumptions in CCN closure studies, using a consistent model approach, based on data sets collected at very different locations and distances from sources. Unlike previous $\mathrm{CCN}$ studies (some of which analyzed in detail the same data sets as those considered here), it is not attempted to deduce exact size/composition/mixing state parameters of the $\mathrm{CCN}$-active particle population based on all measurements, but rather to evaluate the extent to which simple assumptions can reproduce measured $\mathrm{CCN}$ number concentrations across all data sets. A simple treatment of $\mathrm{CCN}$ composition/mixing state as a function of distance from sources would be highly useful for the description of aerosol-cloud interactions in largescale models.

\section{Data sets}

$\mathrm{CCN}$ data sets at six locations that differ in proximity to pollution sources, aerosol loading and composition have been analyzed; details on these data sets and corresponding publications are summarized in Table 1. Three data sets are split into two subsets: During the first period of the MASE experiment at Point Reyes, CA (PYE), air masses were transported mainly from the west and did not have any land contact over the three days prior to sampling, whereas air masses during the remainder of the experiment came from the north and north east and thus had continental influence (C. Berkowitz, personal communication, 2010). For some periods during the ICARTT experiment at Chebogue Point (CBG), analysis of the organic mass fraction (OMF) of the aerosol using the Aerodyne aerosol mass spectrometer (AMS) allowed their classification as either anthropogenically or biogenically influenced, respectively (Holzinger et al., 2007; Williams et al., 2007; Zhang, 2010). Note that not all data points could be unambiguously ascribed to such air masses. During GoMACCS, CCN data were collected on the NOAA research vessel Ronald H. Brown both in the Houston Ship Channel (HSC) and along the Houston Gulf Coast (HGC). It has been shown that aerosol composition and processing can differ significantly in these two areas due to different emissions (Bates et al., 2008; Bahreini et al., 2009). At Mexico City T0 (MEX) and Riverside (RVS), the sampling took place at ground sites that were located near and downwind of significant pollution sources. Emissions at the mountain-top at Holme Moss, UK, (HOM) are characterized by the plumes of Manchester, a conurbation of 2.5 million people (distance $\sim 35 \mathrm{~km}$ ), and nearby towns.

\section{Model}

The CCN model employed here is described in detail in previous studies (Ervens et al., 2007; Cubison et al., 2008). In brief, the model is initialized with measured size distributions and $\mathrm{CCN}$ number concentrations at a given supersaturation $(S)$. In the current study, we compare calculated and measured CCN number concentrations at one $S$ for each study in the range of $0.27 \% \leq S \leq 0.44 \%$ (Table 1). This $S$ (range) is the only one available for all data sets. Such low $S$ is encountered in stratus clouds that have a significant influence on the global radiative forcing. Depending on the data set, $S$ is either a constant value for the whole time period or variations in the $\mathrm{CCN}$ counter are taken into account. At this relatively low $S, \mathrm{CCN}$ number concentrations are most sensitive as only a small fraction of the aerosol population is activated and, thus, any change in the number of activated particles (e.g., due to changes in hygroscopicity) could translate to a significant change in activated fraction (Ervens et al., 2007). 
Table 1. Characteristics of the data sets that have been used for CCN closure in the current study.

\begin{tabular}{|c|c|c|c|c|c|c|c|}
\hline & Dates & $\begin{array}{l}\text { Approx distance } \\
\text { to sources } \\
{[\mathrm{km}]}\end{array}$ & $\begin{array}{l}\text { Mean total number } \\
\text { concentration } \\
{\left[\mathrm{cm}^{-3}\right]} \\
( \pm 1 \text { std dev })\end{array}$ & $\begin{array}{l}\text { Mean submicron } \\
\text { organic (BC) mass } \\
\text { fraction } \\
( \pm 1 \text { std dev) }\end{array}$ & $\begin{array}{l}\text { Supersaturation } \\
S[\%] \\
( \pm 1 \text { std dev })\end{array}$ & $\begin{array}{l}\mathrm{CCN} / \mathrm{CN} \\
{[\text { measured] }} \\
( \pm 1 \text { std dev })\end{array}$ & $\begin{array}{l}\text { Detailed CCN } \\
\text { data analysis }\end{array}$ \\
\hline Riverside (RVS), $\mathrm{CA}^{\mathrm{a}}$ & $7 / 16-8 / 15 / 2005$ & close & $15058 \pm 3937$ & $\begin{array}{l}0.61 \pm 0.12 \\
(0.06 \pm 0.06)\end{array}$ & $0.27 \pm 0.05$ & $0.08 \pm 0.03$ & $\begin{array}{l}\text { (Cubison et al., } \\
2008 \text { ) }\end{array}$ \\
\hline Mexico T0 $(\mathrm{MEX})^{\mathrm{b}}$ & $3 / 2006$ & close & $12197 \pm 4712$ & $\begin{array}{l}0.44 \pm 0.15 \\
(0.14 \pm 0.07)\end{array}$ & 0.29 & $0.41 \pm 0.15$ & $\begin{array}{l}\text { (Wang et al., } \\
\text { 2010) }\end{array}$ \\
\hline $\begin{array}{l}\text { Houston, } \mathrm{TX}^{\mathrm{c}} \\
\text { Ship Channel (HSC) }\end{array}$ & $8 / 2-9 / 11 / 2006$ & close & $17867 \pm 14702$ & $0.65 \pm 0.12$ & 0.44 & $0.45 \pm 0.25$ & $\begin{array}{l}\text { (Quinn et al., } \\
\text { 2008) }\end{array}$ \\
\hline Gulf Coast (HGC) & & 10 & $1753 \pm 1258$ & $0.14 \pm 0.11$ & 0.44 & $0.70 \pm 0.18$ & \\
\hline $\begin{array}{l}\text { Holme Moss } \\
(\mathrm{HOM}), \mathrm{UK}\end{array}$ & $11-12 / 2006$ & 35 & $790 \pm 360$ & $\begin{array}{l}0.23 \pm 0.08 \\
(0.23 \pm 0.15)\end{array}$ & $0.30 \pm 0.03$ & $0.47 \pm 0.15$ & $\begin{array}{l}\text { (Corris, } \\
2008)\end{array}$ \\
\hline $\begin{array}{l}\text { Chebogue Point, } \\
\text { Canada }(\mathrm{CBG})^{\mathrm{d}}\end{array}$ & $7 / 1-8 / 15 / 2004$ & several $100 \mathrm{~s}$ & $4041 \pm 4016$ & $0.65 \pm 0.10$ & $0.29 \pm 0.02$ & $0.40 \pm 0.18$ & $\begin{array}{l}\text { (Ervens et al., } \\
\text { 2007) }\end{array}$ \\
\hline CBG biogenic & & & $3957 \pm 2660$ & $0.79 \pm 0.10$ & & $0.27 \pm 0.14$ & \\
\hline CBG anthropogenic & & & $4930 \pm 3944$ & $0.54 \pm 0.13$ & & $0.41 \pm 0.17$ & \\
\hline PYE (all data) $)^{\mathrm{e}}$ & $7 / 2005$ & several $100 \mathrm{~s}$ & $755 \pm 491$ & $0.10 \pm 0.06$ & $0.29 \pm 0.004$ & $0.59 \pm 0.26$ & \\
\hline PYE - sea & & & $826 \pm 432$ & $0.14 \pm 0.06$ & & $0.59 \pm 0.21$ & \\
\hline PYE - land & & & $694 \pm 557$ & $0.07 \pm 0.04$ & & $0.59 \pm 0.30$ & \\
\hline
\end{tabular}

${ }^{a}$ Study of Organic Aerosols at Riverside, CA (SOAR-I); ${ }^{b}$ Local and Global Research Observations (MILAGRO); ${ }^{c}$ Gulf of Mexico Atmospheric Composition and Climate Study (GoMACCS); ${ }^{\mathrm{d}}$ International Consortium for Atmospheric Research on Transport and Transformation (ICARTT); measurement site located in Nova Scotia, Canada; ${ }^{\text {e }}$ Marine Stratus/Stratocumulus Experiment (MASE), off the coast of Monterey, CA.

Aerosol composition in the model is constrained with time-dependent bulk (i.e., not size-resolved) mass fractions of sub-micron non-refractory inorganic ions (sulfate, nitrate, ammonium, chloride) and organics from Aerodyne AMSs (Canagaratna et al., 2007). The mass of black carbon (BC) has been derived based on absorption measurements for the studies in which this data was available.

The water uptake of the particles is calculated using Köhler theory and defining all inorganics as being fully dissolved. The organic fraction is considered as either insoluble or composed of hygroscopic organics (e.g., fulvic acid and small dicarboxylic acids) which translates to hygroscopicity parameters $\kappa_{\text {org }}=0$ or $\kappa_{\text {org }}=0.12$, respectively (Petters and Kreidenweis, 2007). The carbonaceous (organics+BC) fraction is either internally or externally mixed with the inorganic fraction. The four resulting 'composition assumptions' regarding the organic fraction are identical to those in a previous model study (Pierce et al., 2007):

1. Externally mixed, insoluble $\left(\kappa_{\mathrm{org}}=0\right)$ organics (EM-I)

2. Externally mixed, soluble $\left(\kappa_{\mathrm{org}}=0.12\right)$ organics (EM-S)

3. Internally mixed, insoluble $\left(\kappa_{\text {org }}=0\right)$ organics (IM-I)

4. Internally mixed, soluble ( $\left.\kappa_{\mathrm{org}}=0.12\right)$ organics (IM-S)

The composition/mixing state of ambient aerosol populations is likely to be more complex than any of these assumptions. However, in this study, the extent to which these sim- plified composition models lead to reasonable closure for a variety of locations and aerosol types will be explored.

\section{Results and discussion}

\subsection{CCN closure results}

In Table 2, the concentration ratios " $\mathrm{CCN}$ (calculated)/CCN (measured)" are shown for the data sets in Table 1 and four composition cases. For aerosols sampled in source regions as encountered in RVS, MEX, and HSC, there is a high variability in the observed closure depending on the study. $\mathrm{Cu}-$ bison et al. (2008) showed for the RVS data set that freshly emitted, hydrocarbon-like organics at RVS comprise an externally mixed population with a significant contribution to the total number concentration of particles with a diameter of $D \sim 100 \mathrm{~nm}$. A similar situation is encountered in Mexico City and the Houston Ship Channel where a significant fraction of the particles are fresh (especially from the late evening to the early morning) and have not yet undergone much physical or chemical transformation. In such scenarios, even the assumption of insoluble, externally mixed organics (EM-I) with bulk composition may lead to a significant overestimate of $\mathrm{CCN}$ number concentration. In those cases size-resolved composition and mixing state information is required to accurately predict $\mathrm{CCN}$ (Cubison et al., 2008; Twohy and Anderson, 2008). There is significant variability in the CCN prediction biases at these locations, which relate to differences in size-resolved composition and mixing 
Table 2. Average ratios ( \pm 1 std dev) of calculated to measured $\mathrm{CCN}$ number concentrations for several locations and four different assumptions of composition/mixing state ( $\kappa_{\text {org }}$ : hygroscopicity parameter of organic fraction). Best agreement is marked in gray shaded cells, poorest in bold for each location.

\begin{tabular}{llllll}
\hline & $\begin{array}{l}\text { ext. mixed } \\
\kappa_{\text {org }}=0 \\
(\text { EM-I })\end{array}$ & $\begin{array}{l}\text { ext. mixed } \\
\kappa_{\text {org }}=0.12 \\
(\text { EM-S })\end{array}$ & $\begin{array}{l}\text { int. mixed } \\
\kappa_{\text {org }}=0 \\
(\text { IM-I })\end{array}$ & $\begin{array}{l}\text { int. mixed } \\
\kappa_{\text {org }}=0.12 \\
(\text { IM-S })\end{array}$ & \# data points \\
\hline RVS & $4.4 \pm 1.8$ & $4.9 \pm 1.7$ & $4.6 \pm 1.7$ & $\mathbf{6 . 0} \pm \mathbf{2 . 1}$ & 306 \\
MEX & $0.5 \pm 0.2$ & $1.1 \pm 0.1$ & $0.5 \pm 0.2$ & $\mathbf{1 . 1} \pm \mathbf{0 . 2}$ & 198 \\
HSC & $2.4 \pm 1.9$ & $4.0 \pm 3.0$ & $4.0 \pm 3.0$ & $\mathbf{4 . 2} \pm \mathbf{3 . 2}$ & 120 \\
HGC & $1.9 \pm 1.1$ & $\mathbf{2 . 4} \pm \mathbf{1 . 9}$ & $1.7 \pm 1.0$ & $2.3 \pm 1.9$ & 123 \\
HOM & $1.0 \pm 0.5$ & $\mathbf{1 . 2} \pm \mathbf{0 . 6}$ & $0.8 \pm 0.5$ & $0.9 \pm 0.5$ & 769 \\
CBG - all data & $0.7 \pm 0.3$ & $1.2 \pm 0.3$ & $0.9 \pm 0.4$ & $\mathbf{1 . 4} \pm \mathbf{0 . 4}$ & 717 \\
CBG anthrop. & $0.8 \pm 0.3$ & $1.2 \pm 0.4$ & $1.2 \pm 0.4$ & $\mathbf{1 . 6} \pm \mathbf{0 . 4}$ & 194 \\
CBG biogenic & $0.4 \pm 0.2$ & $1.2 \pm 0.3$ & $0.6 \pm 0.3$ & $\mathbf{1 . 5} \pm \mathbf{0 . 4}$ & 80 \\
PYE - all data & $\mathbf{1 . 3} \pm \mathbf{0 . 6}$ & $\mathbf{1 . 3} \pm \mathbf{0 . 6}$ & $1.1 \pm 0.6$ & $1.1 \pm 0.6$ & 880 \\
PYE land & $\mathbf{1 . 3} \pm \mathbf{0 . 7}$ & $\mathbf{1 . 3} \pm \mathbf{0 . 7}$ & $1.2 \pm 0.6$ & $1.2 \pm 0.6$ & 448 \\
PYE sea & $1.3 \pm 0.5$ & $\mathbf{1 . 4} \pm \mathbf{0 . 5}$ & $0.8 \pm 0.4$ & $0.9 \pm 0.4$ & 432 \\
\hline
\end{tabular}

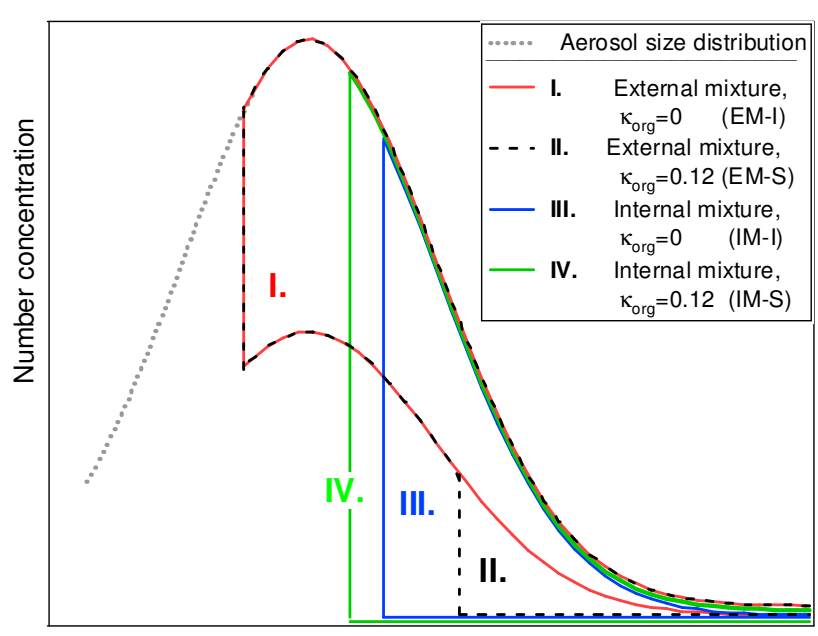

Particle size

Fig. 1. Schematic of areas of activated number concentrations for different composition/mixing state assumptions.

state which are not captured by any of the simplified assumptions of this study. Whereas MEX and RVS resemble one another in terms of average organic fraction and distance from sources, single particle analysis at both locations has shown that the former location is more influenced by (aged) biomass burning particles (Moffet et al., 2008) whereas the latter one showed high fractions of elemental carbon in the diameter range below $200 \mathrm{~nm}$, i.e. around the critical diameter for particles that activate at $S=0.3 \%$ (Spencer et al., 2007).

While inappropriate assumptions about organic composition/mixing state could lead to the overprediction of the $\mathrm{CCN}$ number concentration, there is also the possibility that an apparent overprediction is really a result of the measured CCN number concentration being too low due to instrumental limitations at high particle loading. However, at $S \sim 0.3 \%$ a significant underprediction only occurs for $\mathrm{CCN}$ number concentrations on the order of $30000 \mathrm{~cm}^{-3}$ (Droplet Measurement Technology Inc, 2004). Even though the total particle number concentration occasionally exceeded this value significantly, the average activated fraction at $S \sim 0.3 \%$ never exceeded 0.2 (Cubison et al., 2008) which results in a maximum CCN number concentration of $\sim 6000 \mathrm{~cm}^{-3}$.

In Fig. 1, a schematic size distribution is shown and subpopulations that are predicted to activate for each of the four composition assumptions are marked. If two composition/mixing state assumptions result in similar predicted CCN number concentrations, it does not imply that the same subset of the particle distribution is predicted to activate. It is evident that canceling effects leading to comparable predicted CCN numbers depend on the shape of the size distribution and the magnitude of the organic fraction. None of the four suggested assumptions represents the real composition/mixing state of an atmospheric particle population. There is an infinite number of other (more complex) composition/mixing states that can lead to the same predicted CCN number.

At locations with small organic fractions (HGC, PYE, HOM), the different composition/mixing state assumptions only lead to small changes in the overall quality of the $\mathrm{CCN}$ closure. At locations with higher organic fractions, internally and externally mixed insoluble organics or internally and externally mixed soluble organics, respectively, consistently give similar predicted $\mathrm{CCN}$ number concentrations, i.e. the areas I and III, and the areas II and IV, respectively, in Fig. 1 are similar on average for all observed size distributions which shows that the assumed mixing state is less important than the assumed hygroscopicity of the organics. 
In some cases canceling effects of predicting different parts of the size distribution to activate (Fig. 1) can lead to similar predicted $\mathrm{CCN}$ number concentrations that are within a factor of two to the measured ones with several assumptions.

With increasing distance from pollution sources, the prediction of CCN number concentration under the assumption that all particles contain some hygroscopic material is improved, but no clear statement can be made whether physical or chemical mixing/ageing dominates as similar CCN ratios are predicted by applying cases EM-S or IM-I. The relative importance of mixing/ageing processes depends on factors that cannot be quantified in the present study, such as different photochemical activity and/or oxidant levels due to seasonal effects or concentration levels of precursors. Field studies and model simulations using results from laboratory experiments have suggested that chemical ageing of organic aerosols is too slow and limited to account for efficient hydrophobic-to-hydrophilic conversion as compared to physical mixing processes, especially condensation of hygroscopic secondary inorganic species across the whole particle population (Petters et al., 2006; DeGouw and Jimenez, 2009).

\subsection{Spatial scale of ageing}

In large-scale models, a time scale on the order of 1-2 days is assumed to convert particles from hydrophobic to hygroscopic, and, thus into potential CCN (Wilson et al., 2001). Aerosol age depends not only on distance from source but also on transport and processing time to the sampling site. However, wind data or highly time-resolved back trajectories that could allow an estimate of transport age are only available for a subset of the data sets investigated here. The relative age of air masses is often characterized by its 'photochemical age', which is calculated based on the ratio of $\mathrm{NO}_{\mathrm{x}} / \mathrm{NO}_{\mathrm{y}}$, benzene/toluene, $\mathrm{BC} / \mathrm{CO}$ or oxidized/total organic aerosol mass. This photochemical age is not an absolute value that can be compared for different locations since it is also function of oxidant levels. Since none of these parameters is available for all the data sets used in this study, the present analysis explores spatial ageing scales by comparing distances from sources.

In Fig. 2, the range of the CCN (calculated)/CCN (measured) ratios, weighted by the frequency in the $\mathrm{CCN}$ closure studies, is shown for internally and externally mixed organics. No specific distance is ascribed to the sampling locations close to pollution sources (MEX, HSC, and RVS) because of the various pollution sources close to or within a few kilometers of the sampling location.

For studies downwind of but relatively close to major source areas (HOM and HGC), best CCN closure is achieved if all particles are assumed to be hygroscopic. This might be reasonable because of chemical and/or physical particle processing or due to the fact that the initial particle population dilutes and the resulting aerosol population is mostly determined by aged background aerosol. Applying IM-I (or EM-I) for remote locations as has been done in many global model applications will lead to an underestimate of $\mathrm{CCN}$ number concentrations. Our analysis indicates that, based on two studies (HGC and HOM), the ageing scale of particles is much shorter than several days and could be on the order of hours in agreement with a recent model study that explores the ageing time scale for soot particles (Riemer et al., 2010). This result for locations where photochemistry is active confirms studies that have shown that the addition of a few percent of soluble material to a hydrophobic particle significantly enhances its CCN ability (Bilde and Svenningsson, 2004).

\subsection{Role of organic fraction}

The data sets explored here, cover a wide range of OMF ranging from $7 \pm 4 \%$ to $79 \pm 10 \%$ (Table 1). For an aerosol with small OMF, the assumption of organic composition/mixing state is not crucial since the fractions of the size distributions that are predicted to activate due to hygroscopic and/or internally mixed organics are small (Fig. 1). For high OMF, however, predicted CCN number concentrations are quite sensitive to the assumptions on mixing state/composition and quite different closure results are found.

In Fig. 3a-d, the ranges of predicted $\mathrm{CCN}$ (calculated)/CCN (measured) ratio are shown as a function of OMF for all data sets and all composition cases. Despite much scatter around unity, the predicted $\mathrm{CCN}$ number agrees within a factor of two or better for small OMF under all assumptions (as also reflected in Table 2). As organic fractions increase above $\sim 50 \%$ (MEX, CBG, HSC), it is evident that $\mathrm{CCN}$ number concentrations are increasingly underestimated if insoluble organics (EM-I or IM-I) are assumed (Fig. 3a and b), but reasonably well predicted for the EM$\mathrm{S}$ and IM-S assumptions. This is in agreement with the study by Wang et al. (2008) who found that the best closure for aerosol with $\mathrm{OMF}>70 \%$ can be achieved if a hygroscopicity of $\kappa_{\mathrm{org}}=0.12$ (IM-S) is assumed. The overestimate of CCN number concentration for some of the fresh aerosol (HSC, RVS), as discussed in Sect. 4.1, decreases slightly as OMF increases but this improvement may be a fortuitous result of compensating factors.

\section{Comparison to previous CCN studies}

In Table 3, we have summarized results of multiple previous $\mathrm{CCN}$ studies together with the approximate distance from major pollution sources and the assumptions on organic hygroscopicity and mixing state in the respective CCN studies. Only a few studies have been performed very close to major pollution sources (Broekhuizen et al., 2006; $\mathrm{Cu}-$ bison et al., 2008; Quinn et al., 2008; Lance et al., 2009). 
Table 3. Summary of previous CCN closure studies. "Dist" is the approximate distance from major emission sources, $\kappa_{\text {org }}$ is the hygroscopicity parameter of the organic fraction, $\kappa_{\text {all }}$ is the hygroscopicity parameter of the total aerosol (if $\kappa$ was not provided in the original literature it was derived here based on reported composition/hygroscopicity data); "slope" is the ratio of CCN (calculated)/CCN (measured), and $S$ is the supersaturation (range). If not otherwise noted, all studies assume bulk composition.

\begin{tabular}{|c|c|c|c|c|c|c|c|}
\hline Location & Dist $[\mathrm{km}]$ & $\kappa$ & Mixing state & "slope" & $S[\%]$ & Comment & Reference \\
\hline \multirow[t]{3}{*}{ Riverside } & \multirow[t]{3}{*}{ close } & $\kappa_{\text {org }}=0$ & int & $2.8-7.1$ & $0.1-0.9$ & hydrophobic org at & \multirow[t]{3}{*}{ (Cubison et al., 2008) } \\
\hline & & $\kappa_{\text {org }}=0$ & ext & $0.79-4.1$ & $0.1-0.9$ & $\sim 100 \mathrm{~nm}$ (ext. mixed) size- & \\
\hline & & $\kappa_{\text {org }}=0$ & int/ext & $1-3.7$ & $0.1-0.9$ & resolved composition & \\
\hline Houston (ship) & close & $\kappa_{\text {org }}=0$ & ext & $0.85-1.2$ & $0.22-1$ & $\begin{array}{l}\text { CCN prediction of particles } \\
\sim 200 \mathrm{~nm}\end{array}$ & (Quinn et al., 2008) \\
\hline \multirow[t]{2}{*}{ Houston (aircraft) } & \multirow[t]{2}{*}{ close } & $\kappa_{\mathrm{all}}=0.6$ & int & 1.36 & \multirow[t]{2}{*}{$0.3-1.1$} & Hydrophobic org at & \multirow[t]{2}{*}{ (Lance et al., 2009) } \\
\hline & & $\kappa_{\text {org }}=0$ & int & 1.03 & & $\sim 100 \mathrm{~nm}$ & \\
\hline \multirow[t]{3}{*}{ Toronto } & \multirow[t]{3}{*}{ close } & $\kappa_{\text {org }}=0$ & int & 1.12 & $0.56-0.6$ & assumption: $10 \%$ of org & \multirow[t]{3}{*}{ (Broekhuizen et al., 2006) } \\
\hline & & $\kappa_{\text {org }}=0$ & ext & 1.03 & $0.56-0.6$ & fraction soluble & \\
\hline & & $\kappa_{\text {org }}=0.096$ & int & 1.16 & $0.56-0.6$ & & \\
\hline \multirow[t]{6}{*}{ Mexico City } & \multirow[t]{6}{*}{$\geq 10 \mathrm{~km}$} & \multirow[t]{6}{*}{$\kappa_{\text {org }}=0.15$} & int & $0.99-1.76$ & $0.11-0.35$ & bulk composition & \multirow[t]{6}{*}{ (Wang et al., 2010) } \\
\hline & & & int & $0.89-1.45$ & & size-resolved & \\
\hline & & & int/ext & $0.85-1.12$ & & inorg+OOA and $\mathrm{eBC}+\mathrm{HOA}$ & \\
\hline & & & ext & $0.74-1.03$ & & ext. mixed & \\
\hline & & & ext & $0.82-1.08$ & & $\begin{array}{l}\text { all components ext. mixed, } \\
\text { size-resolved }\end{array}$ & \\
\hline & & & & & & $\begin{array}{l}\text { all components ext. mixed, } \\
\text { bulk }\end{array}$ & \\
\hline New Hampshire & & $\kappa_{\text {org }}=0$ & int & 1.22 & 0.3 & size-resolved composition & (Medina et al., 2007) \\
\hline (Thompson Farm) & & $\kappa_{\text {org }}=0$ & int & 1.052 & 0.3 & & \\
\hline Vancouver & 45 & $\begin{array}{l}0.001<\kappa_{\text {org }} \\
<0.11\end{array}$ & int & $\sim 0.8-1$ & $0.19-0.5$ & $\kappa_{\text {all }}=0.6$, size-resovled & (Shantz et al., 2008) \\
\hline Guangzhou (China) & 60 & $\kappa_{\mathrm{all}}=0.32 \pm 0.1$ & int & $1.0 \pm 0.07$ & 0.27 & $\begin{array}{l}\kappa \text { derived based on } \\
\text { HTDMA }\end{array}$ & (Rose et al., 2010) \\
\hline \multirow[t]{3}{*}{ Toronto (rural) } & \multirow[t]{3}{*}{70} & $\kappa_{\text {org }}=0$ & int & $0.89-1.14$ & 0.42 & & \multirow[t]{3}{*}{ (Chang et al., 2009) } \\
\hline & & $\kappa_{\mathrm{OX}}=0.2$ & int & 1.23 & 0.42 & & \\
\hline & & $\kappa_{\text {non }-\mathrm{ox}}=0$ & & & & & \\
\hline \multirow[t]{2}{*}{ Duke Forest (polluted) } & \multirow[t]{6}{*}{$10 \mathrm{~s}$} & $\kappa_{\text {org }}=0.13$ & int & $1.7-2.1$ & 0.2 & & (Stroud et al., 2007) \\
\hline & & $\kappa_{\text {org }}=0$ & & $1.4-1.65$ & & & \\
\hline \multirow[t]{4}{*}{ Monterey } & & $\kappa_{\text {org }}=0$ & int & $0.94-0.95$ & 0.2 & boundary layer and free tro- & \multirow{4}{*}{ (Wang et al., 2008) } \\
\hline & & $\kappa_{\text {org }}=0.25$ & int & $1.1-1.15$ & 0.2 & posphere & \\
\hline & & $\kappa_{\text {org }}=0.1$ & int & 1.17 & 0.2 & above clouds & \\
\hline & & $\kappa_{\text {org }}=0.1$ & ext & 0.89 & 0.2 & above clouds & \\
\hline Californian Coast & & $\kappa_{\mathrm{all}}=0.13$ & int & $\sim 1$ & 0.6 & $\kappa$ derived based on & (Furutani et al., 2008) \\
\hline & & & & & & $D_{\text {crit, mean }}(66.7 \mathrm{~nm})$ & \\
\hline Jeju Island & $100 \mathrm{~s}$ & $\kappa_{\mathrm{all}}=0.17$ & int & 0.73 & $0.1-1$ & & (Kuwata et al., 2008) \\
\hline & & $\kappa_{\mathrm{all}}=0.6$ & int & 1.16 & & & \\
\hline North Sweden & $100 \mathrm{~s}$ & $\kappa_{\text {org }}=0.09$ & int & 1.12 & 0.6 & $\begin{array}{l}\text { size-dependent } \kappa \text { derived } \\
\text { based on HTDMA }\end{array}$ & (Kammermann et al., 2010) \\
\hline N American Coast & $80-1000$ s & $\kappa_{\text {all }}=0.6$ & int & $\sim 1-1.5$ & 0.3 & $\mathrm{CCN}$ closure results & (Roberts et al., 2010) \\
\hline Free troposphere & & & & & & reported for whole data set & \\
\hline Central Valley & & & & & & (aircraft data) & \\
\hline & & & & & & $\begin{array}{l}\text { Assumption: pure } \\
\left(\mathrm{NH}_{4}\right)_{2} \mathrm{SO}_{4}\end{array}$ & \\
\hline Northeast Atlantic & & $\kappa_{\mathrm{org}}=0$ & int & 0.34 & 0.1 & instrumental errors (?) & (Chuang et al., 2000) \\
\hline Tasmania & & $\kappa_{\text {org }}=0$ & int & $1.26(0.99)$ & 0.5 & $\begin{array}{l}\text { Better agreement in air } \\
\text { masses with low aerosol } \\
\text { loading and Rn }\end{array}$ & (Covert et al., 1998) \\
\hline North Pacific & & $\kappa_{\text {org }}<0.5$ & int & $0.6-1.15$ & 0.34 & size-resolved & (Shantz et al., 2008) \\
\hline Remote, marine & & $\kappa_{\text {org }}=0$ & int & 0.92 & 0.38 & & (Bougiatoti et al., 2009) \\
\hline & & $\kappa_{\text {org }}=0.158$ & int & 0.98 & & & \\
\hline Eastern Pacific & & $\kappa_{\mathrm{all}}=0.6$ & int & 1.78 & 0.3 & & (Roberts et al., 2006) \\
\hline Amazon & & $\kappa_{\text {org }}=0$ & int & $0.2-0.3$ & $0.2-1$ & & (Mircea et al., 2002) \\
\hline & & $\kappa_{\mathrm{org}} \sim 0.1$ & int & $0.5-1$ & & & \\
\hline Amazon & & $\kappa_{\text {org }}=0.1$ & int & 1.17 & $0.1-0.82$ & size-resolved composition & (Gunthe et al., 2009) \\
\hline Amazon & & $\kappa_{\text {org } 1}=0.03$ & int & 1.11 & $0.3-1$ & 2 internally modes of & (Rissler et al., 2006) \\
\hline & & $\kappa_{\mathrm{org} 2}=0.1$ & ext & 1.06 & & different sizes & \\
\hline
\end{tabular}



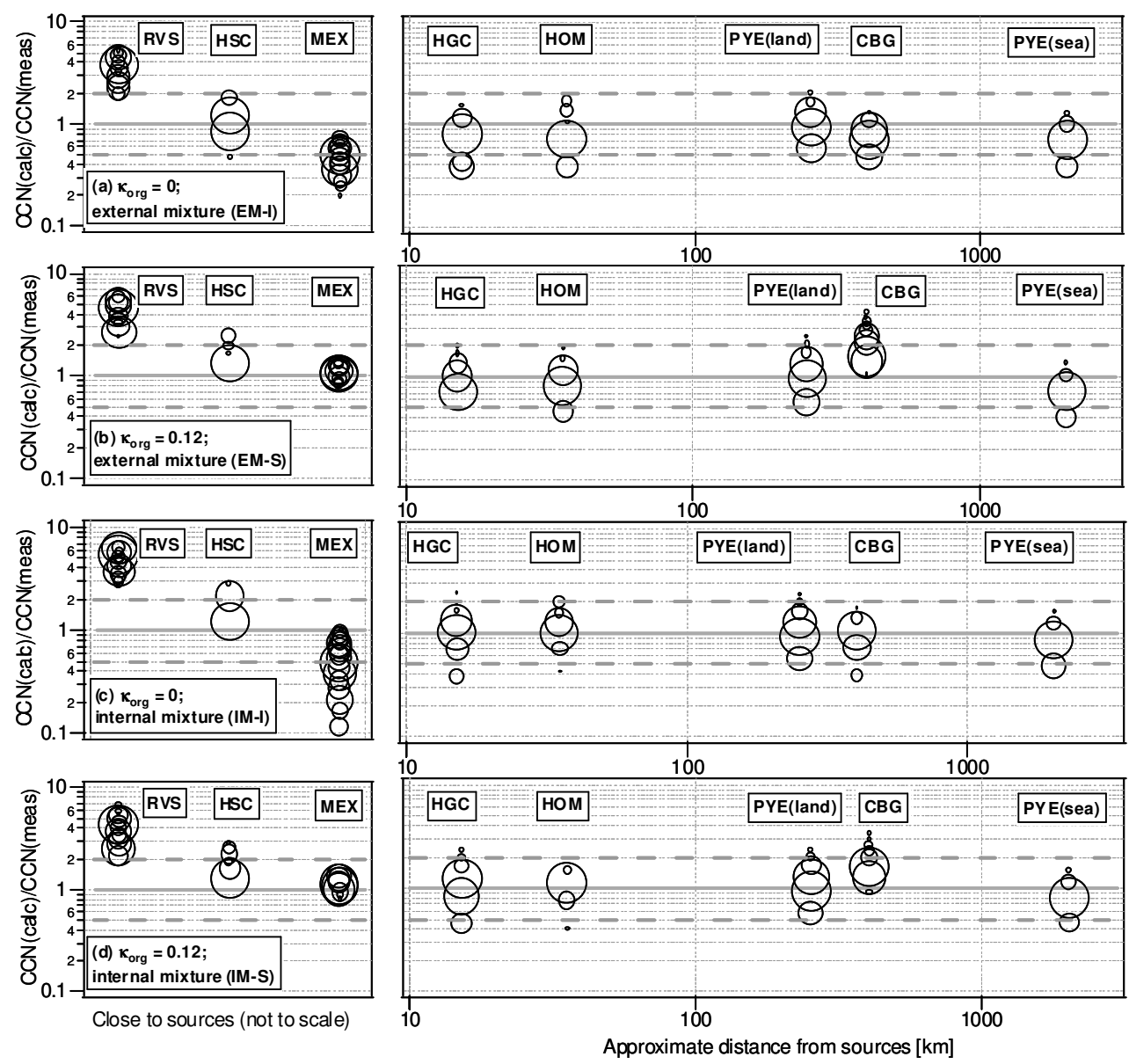

Fig. 2. Ratio of calculated to measured $\mathrm{CCN}$ number concentration for seven different data sets. The symbol size corresponds to the frequency of the respective ratio in the CCN closure. Horizontal lines denote the 1:1 line (solid line) and ratios of 0.5 and 2 (dashed lines), respectively.

These studies agree that best closure can be achieved if size-resolved chemical composition is taken into account with particular consideration of freshly emitted hydrophobic organics. Size-resolved particle analysis of particle data sets in Tokyo and Guanzhou has confirmed the existence of such a mode around $D \sim 100 \mathrm{~nm}$ (Kuwata and Kondo, 2008; Rose et al., 2010). Several studies of hygroscopic growth factor measurements in urban environments confirm the existence of a less hygroscopic mode that is composed of freshly-emitted hydrophobic particles (Swietlicki et al., 1999; Cocker et al., 2001; Väkevä et al., 2002). Since the critical diameter of $\mathrm{CCN}$ is usually in the size range of $\sim 50$ $200 \mathrm{~nm}$ (depending on $S$ and composition), the consideration of this 'small-size' mode is crucial for CCN closure studies and ignoring it will lead to an overestimate of the CCN number concentration. A recent CCN study of the data set in Mexico City has shown that this mode is most prominent in the morning and best closure is achieved if hydrocarbon-like organics (HOA) and $\mathrm{BC}$ is assumed to be externally mixed with the inorganic and oxygenated organic fraction. In the afternoon, this composition/mixing state assumption leads to an underestimate of $\mathrm{CCN}$ and the assumption of internally mixed, size-resolved composition gives best closure results (Wang et al., 2010). The good closure results in the latter study that are obtained by assuming bulk composition and an external mixture of all components might be fortuitous due to canceling effects of an overestimate by assuming bulk composition and an underestimate due to externally mixed components according to the schematic in Fig. 1.

These studies for polluted conditions and fresh emissions are consistent with findings from a global model study where it has been shown that the largest error in $\mathrm{CCN}$ prediction occurs under polluted conditions and CCN mixing state needs to be taken into account in order to reduce this error to $<10 \%$ (Sotiropulou et al., 2007).

With increasing distance from pollution sources, good $\mathrm{CCN}$ closure results (CCN (calculated)/CCN (measured) $\leq 1.65$ ) have been obtained if the organic fraction is assumed to be insoluble ( $\kappa_{\mathrm{org}}=0$ ) (Medina et al., 2007; Stroud et al., 2007; Shantz et al., 2008; Wang et al., 2008; Chang et al., 

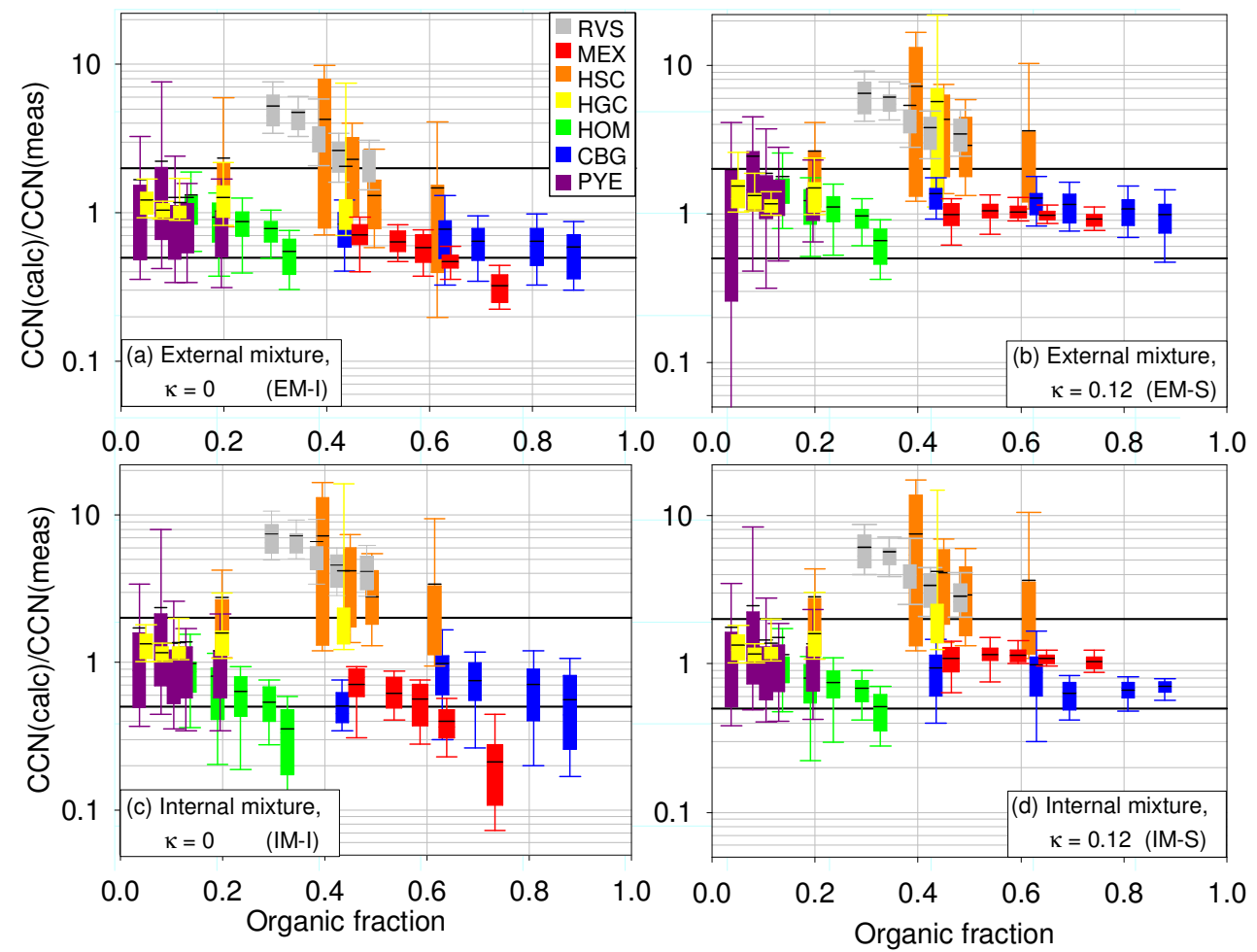

Fig. 3. Ratio of calculated to measured $\mathrm{CCN}$ number concentrations as a function of organic mass fraction for seven different data sets and different assumptions of hygroscopicity and mixing state of the organic fraction. Each bar represents $20 \%$ of the respective data set, error bars show \pm one standard deviation; mean value is marked in each bar. Horizontal black lines represent $\mathrm{CCN}(\mathrm{calculated}) / \mathrm{CCN}(\mathrm{measured})=0.5$ and 2 , respectively.

2009). The assumption of an external mixture of soluble organics leads to an underestimate of the $\mathrm{CCN}$ number but increasing the hygroscopicity of the internally mixed model organics leads to better agreement (Wang et al., 2008). An internal mixture of insoluble organics suggests that indeed physical mixing processes (i.e. condensation of soluble lowvolatility or semivolatile compounds or coagulation) are predominant rather than chemical ageing processes that would result in an external mixture of soluble organics. The dominance of condensation and coagulation is also apparent in fast size-resolved chemistry data (e.g., Zhang et al., 2004).

At remote continental locations with some impact of anthropogenic emissions, CCN closure studies have been successful with the assumption of internally mixed organics with $\kappa_{\text {org }} \sim 0.09$ (Kammermann et al., 2010). In that study, composition measurements were not available; however, the low hygroscopicity parameters $\left(0.07<\kappa_{\text {all }}<0.21\right)$ determined in their studies point to a small inorganic fraction. Those authors have also shown that the sensitivity to the mixing state is not of importance and very similar closure results are found by assuming externally mixed, soluble organics, in agreement with our results for EM-S and IM-S in Figs. 2 and 3. In regions with very high organic fractions such as in the Amazon, the assumption of internally mixed organics with $\kappa_{\text {org }} \leq 0.1$ leads to CCN overprediction of $\leq 17 \%$ (Mircea et al., 2002; Rissler et al., 2006; Gunthe et al., 2009). This range of $\kappa_{\text {org }}$ is in agreement with the hygroscopicity suggested for secondary organic aerosol (Petters and Kreidenweis, 2007).

During studies at remote locations, size-resolved composition measurements were available. Even though all aged particles are to some extent internally mixed, larger particles generally exhibit a higher hygroscopicity due to their growth by condensation of soluble compounds (sulfate, organics) (Furutani et al., 2008; Gunthe et al., 2009; Kammermann et al., 2010). An average hygroscopicity might be biased to larger values if it is averaged based on volume of the size distribution. If particles around the critical diameter have a distinctly smaller hygroscopicity, applying this average value for the whole size distribution will lead to an overestimate (Medina et al., 2007).

The trends in $\kappa_{\text {org }}$ in Table 3, together with the findings in Fig. 2, can be used as general guidance for the treatment of the organic fraction in CCN studies. All data sets confirm that size-resolved organic composition and mixing state are of importance in highly polluted areas with fresh emissions, whereas condensation and/or coagulation is efficient enough to convert hydrophobic organic particles within 

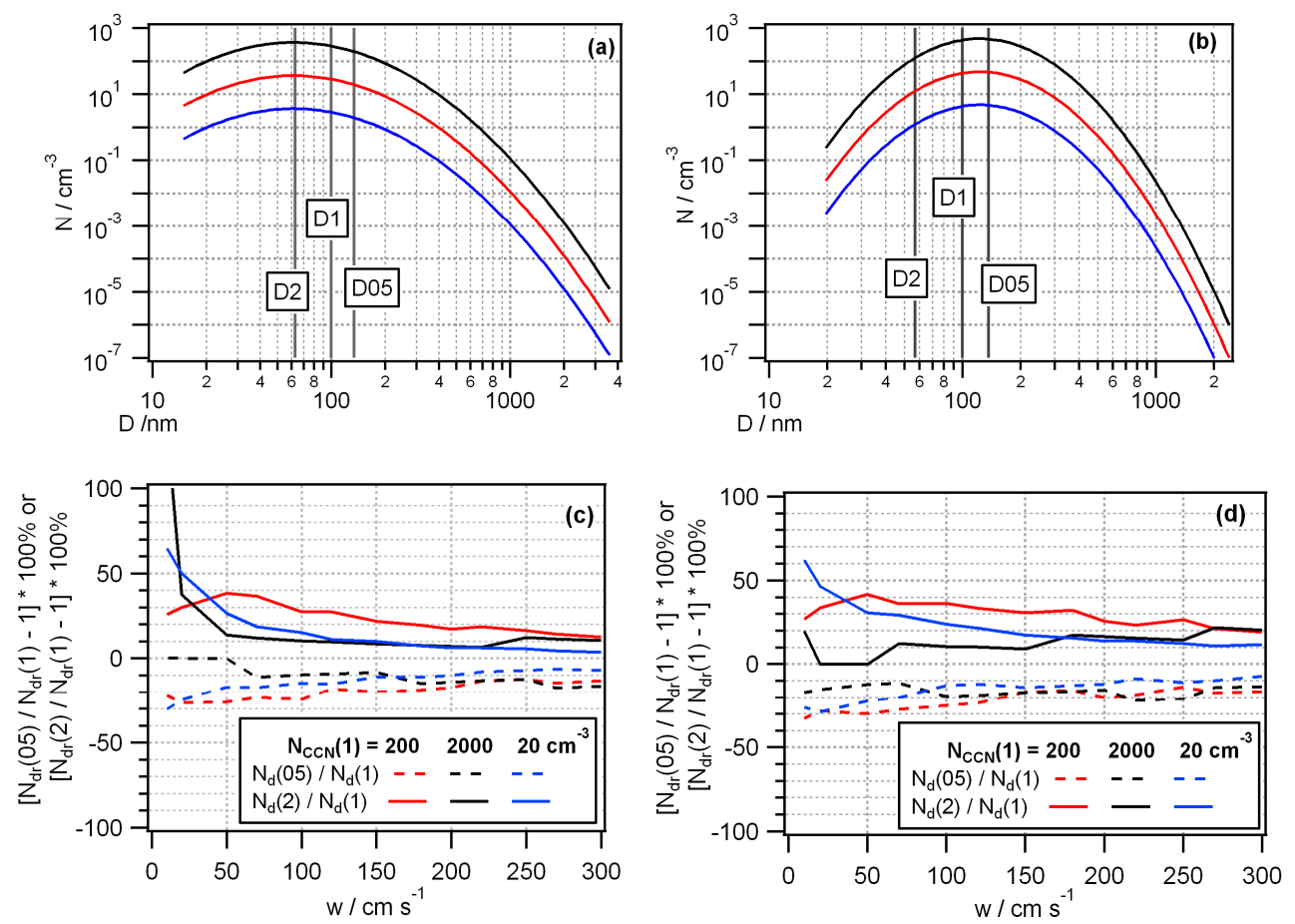

Fig. 4. (a) and (b) Example size distributions that are used as input data to the cloud parcel model. D1 denotes the critical diameter for particles that are activated at $S=0.3 \%, \kappa=0.18$ ("base case"). $D 05$ and $D 2$ denote the critical diameters for particles with a composition that result in $50 \%$ or $200 \%$, respectively, of the activated number concentration as compared to the base case. (c) and (d) Relative difference between predicted drop number concentration for the compositions $\kappa 05$ and $\kappa 2$ to predicted drop number concentration using $\kappa 1$ as a function of updraft velocity in the cloud parcel model.

short distances into hygroscopic particles (internal mixture, $\kappa_{\text {org }}=0$ ). With increasing distance from pollutions sources, the initially hydrophobic organic particles become hygroscopic due to additional hygroscopic material and the organic fraction can be represented with an overall organic hygroscopicity $0<\kappa_{\text {org }}<0.2$.

\section{Effects of uncertainty in $\mathrm{CCN}$ number concentration on drop number concentration $\left(N_{\mathrm{d}}\right)$}

While CCN studies are helpful in order to test our understanding of the physico-chemical properties of aerosol particles that affect their CCN ability, the supersaturation in a cloud is not only controlled by the condensational sink of water vapour but to a large extent by dynamic processes, such as the cooling rate due to the updraft. In previous theoretical studies, it has been shown that any chemical effects on CCN number concentration are reduced when cloud drop numbers (and not $\mathrm{CCN}$ in equilibrium) are compared (Ervens et al., 2005; Sotiropulou et al., 2007; Cubison et al., 2008; Wang et al., 2008).

By means of a theoretical model approach, we explore the extent to which an error of a factor of two due to inappropriate composition assumptions in CCN closure studies (Figs. 2 and 3) translates into an error in drop number concentration. This model approach has been used before to describe the activation of aerosol particles at a constant updraft velocity (Ervens et al., 2005; Cubison et al., 2008). The initial size distribution for these exemplary model runs is lognormal with geometrically distributed diameters between $0.02-2 \mu \mathrm{m}$. It is assumed that all particles are internally mixed and have the same composition throughout the size range.

A reference composition $(\kappa=0.18)$ has been defined that translates into a critical diameter $D 1$ at $S=0.3 \%$ according to Köhler theory. The number concentration of the aerosol distribution is chosen in a way that this base case has a CCN number concentration of $400 \mathrm{~cm}^{-3}$. In sensitivity studies to simulate more/less polluted scenarios, the total particle number has been scaled up/down by a factor $10\left(4000 \mathrm{~cm}^{-3}\right.$, $40 \mathrm{~cm}^{-3}$; Fig. 4a, b).

For sensitivity studies, an error of two in the base case $\mathrm{CCN}$ number is introduced by varying $\kappa$ in a way that the resulting critical diameters $D 2$ and $D 05$ describe a concentration that is twice/half as large as that constrained by $D 1$ at $S=0.3 \%$ (Fig. $4 \mathrm{a}, \mathrm{b}$ ). The two size distributions show that the values of $D 1$ and $D 2$ depend on the shape of the size distribution since different fractions are predicted to activate. The calculations are performed for two different size distributions in order to explore the impact of the size 
distributions. Unlike in previous studies that have explored the effect on cloud drop number concentration due to an error in aerosol number concentration (e.g., Feingold, 2003; Ervens et al., 2005), in the current study different compositions with a constant aerosol number concentration are input parameters for the sensitivity runs and the difference in predicted CCN number concentration only hold for $S=0.3 \%$. At different $S$, the ratio of the predicted $\mathrm{CCN}$ number concentration will differ from two.

The compositions $(\kappa 1, \kappa 05, \kappa 2)$ and size distributions are used as input to the cloud model and simulations are performed for updraft velocities $w$ in the range of $10 \mathrm{~cm} \mathrm{~s}^{-1}<$ $w<300 \mathrm{~cm} \mathrm{~s}^{-1}$. Drop number concentrations from each simulation $\left(N_{\mathrm{d}}(1), N_{\mathrm{d}}(05), N_{\mathrm{d}}(2)\right)$ are compared at a maximum liquid water content of $0.3 \mathrm{~g} \mathrm{~m}^{-3}$. In Fig. $4 \mathrm{c}$ and $\mathrm{d}$, the ratios $\left[N_{\mathrm{d}}(05) / N_{\mathrm{d}}(1)-1\right]$ and $\left[N_{\mathrm{d}}(2) / N_{\mathrm{d}}(1)-1\right]$ are shown as a function of $w$. A value of $\pm 100 \%$ corresponds to the same uncertainty as in the comparison of the $\mathrm{CCN}$ number concentration whereas $50 \%$ denotes that the error in cloud drop number prediction is only half of that as in $\mathrm{CCN}$ number prediction. At $w=10 \mathrm{~cm} \mathrm{~s}^{-1}$, the difference in drop number concentration is greatest for both initial size distributions and might be as large as a factor of two. As opposed to findings that suggested the largest effect at high particle number concentration, i.e. if condensation might significantly impact the supersaturation (Ervens et al., 2005), the results in Fig. 4c and $\mathrm{d}$ do not show a clear trend in terms of the total particle number concentration.

With increasing updraft velocity, the supersaturation is mostly controlled by the cooling rate and the sink term due to condensation of water vapour becomes negligible. At $w \sim 300 \mathrm{~cm} \mathrm{~s}^{-1}$, the change in drop number concentration due to different assumptions of particle composition $(\kappa)$ is reduced to about $10-20 \%$ as compared to the ratio of 2 in the CCN number concentrations. This range is in agreement with findings from similar studies (Ervens et al., 2005; Sotiropoulou et al., 2006). This uncertainty might translate into an error of regional indirect forcing of $\sim 0.5 \mathrm{~W} \mathrm{~m}^{-2}$; however, these are regions where the total indirect radiation is high, and thus the relative error in indirect forcing is small (Sotiropoulou et al., 2006; 2007). In the latter studies, it has been concluded that the error in CCN prediction is small for the indirect forcing because the clouds that contribute most to the indirect effect are those at moderate pollution levels. As shown in the current study, in these regions, however, CCN can be predicted reasonably well without detailed knowledge of composition and mixing state.

\section{Summary and conclusions}

$\mathrm{CCN}$ closure results for six different locations are compared using four simplified composition/mixing state assumptions for the carbonaceous (organics+BC) aerosol fraction (soluble/insoluble, internally/externally mixed with inorganic fraction). Despite very different locations and air masses, the following trends can be identified:

- Very close to pollution sources, simple assumptions of organic mixing state/ solubility and bulk composition are not sufficient to predict $\mathrm{CCN}$ number concentrations. More complex assumptions about composition and mixing state (e.g., size-resolved) need to be made.

- Externally mixed, hydrophobic organic particles are likely to be sufficiently processed by chemical and/or physical ageing within a few tens of kilometers downwind of emission sources such that $\mathrm{CCN}$ composition can be reasonably well represented by externally mixed, hygroscopic organics.

- Different assumptions for organic solubility and mixing state often lead to similar $\mathrm{CCN}$ number concentrations since different subsets of the aerosol population are predicted to activate. Thus, reasonable CCN closure may be achieved due to such compensating factors even though the assumed composition/mixing state might not represent the true properties of the aerosol population.

- A factor of two error in $\mathrm{CCN}$ concentration due to composition effects will translate to an error of about 10 $20 \%$ in cloud drop concentration in agreement with previous studies that compared effects on drop number concentration due to different aerosol number concentrations (Ervens et al., 2005; Cubison et al., 2008).

Our results provide a general framework that allows prediction of CCN number concentrations to better than a factor of two on average for a variety of scenarios where the aerosol has undergone some degree of ageing by making simple assumptions about the solubility and mixing state of the organic fraction. Given the rather poor representation of clouds in large-scale models, the error in drop number concentration due to uncertainties in $\mathrm{CCN}$ number concentrations is relatively small compared to radiative forcing uncertainties associated with macroscale cloud properties such as cloud fraction and depth.

Acknowledgement. BE (MJC, JLJ and QZ) acknowledge funding from the U.S. Department of Energy (BER, ASP Program), Grant DE-FG02-08ER64539 (DE-FG02-08ER64627).

Edited by: A. Nenes

\section{References}

Bahreini, R., Ervens, B., Middlebrook, A. M., Warneke, C., DeGouw, J. A., DeCarlo, P., Jimenez, J. L., Brock, C. A., Neuman, J. A., Ryerson, T. B., Stark, H., Atlas, E., Brioude, J., Fried, A., Holloway, J. S., Peischl, J., Richter, D., Walega, J., Weibring, P., Wollny, A. G., and Fehsenfeld, F. C.: Organic aerosol formation in urban and industrial plumes in Houston, TX, J. Geophys. Res., 114, D00F16, doi:10.1029/2008JD011493, 2009. 
Bates, T. S., Quinn, P. K., Coffman, D., Schulz, K., Covert, D. S., Johnson, J. E., Williams, E. J., Lerner, B. M., Angevine, W. M., Tucker, S. C., and Brewer, W. A., and Stohl, A.: Boundary layer aerosol chemistry during TexAQS/GoMACCS 2006: Insights into aerosol sources and transformation processes, J. Geophys. Res., 113, D00F01, doi:10.1029/2008JD010023, 2008.

Bilde, M. and Svenningsson, B.: CCN activation of slightly soluble organics: the importance of small amounts of inorganic salt and particle phase, Tellus, 56B, 128-134, 2004.

Bougiatioti, A., Fountoukis, C., Kalivitis, N., Pandis, S. N., Nenes, A., and Mihalopoulos, N.: Cloud condensation nuclei measurements in the marine boundary layer of the Eastern Mediterranean: CCN closure and droplet growth kinetics, Atmos. Chem. Phys., 9, 7053-7066, doi:10.5194/acp-9-7053-2009, 2009.

Broekhuizen, K., Chang, R.Y.-W., Leaitch, W. R., Li, S.-M., and Abbatt, J. P. D.: Closure between measured and modeled cloud condensation nuclei (CCN) using size-resolved aerosol compositions in downtown Toronto, Atmos. Chem. Phys., 6, 2513-2524, doi:10.5194/acp-6-2513-2006, 2006.

Canagaratna, M. R., Jayne, J. T., Jimenez, J. L., Allan, J. D., Alfarra, M. R., Zhang, Q., Onasch, T. B., Drewnick, F., Coe, H., Middlebrook, A., Delia, A., Williams, L. R., Trimborn, A. M., Northway, M. J., DeCarlo, P. F., Kolb, C. E., Davidovits, P., and Worsnop, D. R.: Chemical and microphysical characterization of ambient aerosols with the Aerodyne Aerosol Mass Spectrometer, Mass Spectrometry Reviews, 26, 185-222, 2007.

Chang, R. Y.-W., Slowik, J. G., Shantz, N. C., Vlasenko, A., Liggio, J., Sjostedt, S. J., Leaitch, W. R., and Abbatt, J. P. D.: The hygroscopicity parameter $(\kappa)$ of ambient organic aerosol at a field site subject to biogenic and anthropogenic influences: Relationship to degree of aerosol oxidation, Atmos. Chem. Phys. Discuss., 9, 25323-25360, doi:10.5194/acpd-9-25323-2009, 2009.

Chuang, P. Y., Collins, D. R., Pawlowska, H., Snider, J. R., Jonsson, H. H., Brenguier, J. L., Flagan, R. C., and Seinfeld, J. H.: CCN measurements during ACE-2 and their relationship to cloud microphysical properties, Tellus B, 52, 843-867, 2000.

Cocker, D., Whitlock, N., Flagan, R., and Seinfeld, J.: Hygroscopic properties of Pasadena, California aerosol, Aerosol Sci. Technol., 35, 637-647, 2001.

Conant, W. C., T. M. VanReken, T. A. Rissman, V. Varutbangkul, H. H. Jonsson, A. Nenes, J. L. Jimenez, A. E. Delia, R. Bahreini, G. C. Roberts, R. C. Flagan, and Seinfeld, J. H.: Aerosol-cloud drop concentration closure in warm cumulus, J. Geophys. Res., 109, D13204, doi:10.129/2003JD004324, 2004.

Corrigan, C. E. and Novakov, T.: Cloud condensation nucleus activity of organic compounds: a laboratory study, Atmos. Environ., 33, 2661-2668, 1999.

Corris, B.: Atmospheric aerosol: The link between composition and physical behaviour, School of Earth, Atmospheric and Environmental Sciences, The University of Manchester, Manchester (UK), 2008.

Covert, D. S., Gras, J. L., Wiedensohler, A., and Stratmann, F.: Comparison of directly measured $\mathrm{CCN}$ with $\mathrm{CCN}$ modeled from the number-size distribution in the marine boundary layer during ACE 1 at Cape Grim, Tasmania, J. Geophys. Res., 103, D13, doi:10.1029/98jd01093, 1998.

Cruz, C. N. and Pandis, S. N.: Deliquescence and hygroscopic growth of mixed inorganic-organic atmospheric aerosols, Environ. Sci. Technol., 34, 4313-4319, 2000.
Cubison, M. J., Ervens, B., Feingold, G., Docherty, K. S., Ulbrich, I. M., Shields, L., Prather, K., Hering, S., and Jimenez, J. L.: The influence of chemical composition and mixing state of Los Angeles urban aerosol on $\mathrm{CCN}$ number and cloud properties, Atmos. Chem. Phys., 8, 5649-5667, doi:10.5194/acp-8-5649-2008, 2008.

DeGouw, J. and Jimenez, J. L.: Organic aerosols in the Earth's atmosphere: organic particles are abundant in the troposphere and important for air quality and climate - but what are their sources?, Environ. Sci. Technol., 43, 20, 7614-7618, 2009.

Droplet Measurement Technology Inc: Manual, Operator Cloud Condensation Nuclei Counter, Boulder, 2004.

Dusek, U., Frank, G. P., Hildebrandt, L., Curtius, J., Schneider, J., Walter, S., Chand, D., Drewnick, F., Hings, S., Jung, D., Borrmann, S., and Andreae, M. O.: Size matters more than chemistry for cloud-nucleating ability of aerosol particles, Science, 312, 1375-1378, 2006.

Ervens, B., Feingold, G., and Kreidenweis, S. M.: The influence of water-soluble organic carbon on cloud drop number concentration, J. Geophys. Res., 110, D18211, doi:10.1029/2004JD005634, 2005.

Ervens, B., Cubison, M. J., Andrews, E., Feingold, G., Ogren, J. A., Jimenez, J. L., DeCarlo, P., and Nenes, A.: Prediction of cloud condensation nucleus number concentration using measurements of aerosol size distributions and composition and light scattering enhancement due to humidity, J. Geophys. Res., 112, D10S32, doi:10.1029/2006JD007426, 2007.

Feingold, G.: Modeling of the first indirect effect: Analysis of measurement requirements, Geophys. Res. Lett., 30, 19, doi:10.1029/2003GL017967, 2003.

Furutani, H., Dall'osto, M., Roberts, G. C., and Prather, K. A.: Assessment of the relative importance of atmospheric aging on $\mathrm{CCN}$ activity derived from field observations, Atmos. Environ., 42, 3130-3142, 2008.

Gunthe, S. S., King, S. M., Rose, D., Chen, Q., Roldin, P., Farmer, D. K., Jimenez, J. L., Artaxo, P., Andreae, M. O., Martin, S. T., and Pöschl, U.: Cloud condensation nuclei in pristine tropical rainforest air of Amazonia: size-resolved measurements and modeling of atmospheric aerosol composition and CCN activity, Atmos. Chem. Phys., 9, 7551-7575, doi:10.5194/acp-9-75512009, 2009.

Holzinger, R., Milet, D. B., Williams, B., Lee, A., Kreisberg, N., Hering, S. V., Jimenez, J. L., Allan, J. D., Worsnop, D. R., and Goldstein, A. H.: Emission, oxidation, and secondary organic aerosol formation of volatile organic compounds as observed at Chebogue Point, Nova Scotia, J. Geophys. Res., 112, D10S24, doi:10.129/2006JD007599, 2007.

Kammermann, L., Gysel, M., Weingartner, E., Herich, H., Cziczo, D. J., Holst, T., Svenningsson, B., Arneth, A., and Baltensperger, U.: Sub-arctic atmospheric aerosol composition 3: Measured and modeled properties of cloud condensation nuclei (CCN), J. Geophys. Res., 115, D04202, doi:10.1029/2009JD012447, 2010.

Kuwata, M. and Kondo, Y.: Dependence of size-resolved $\mathrm{CCN}$ spectra on the mixing state of nonvolatile cores observed in Tokyo, J. Geophys. Res., 113, D19202, doi:10.1029/2007JD009761, 2008.

Kuwata, M., Kondo, Y., Miyazaki, Y., Komazaki, Y., Kim, J. H., Yum, S. S., Tanimoto, H., and Matsueda, H.: Cloud condensation nuclei activity at Jeju Island, Korea in spring 2005, At- 
mos. Chem. Phys., 8, 2933-2948, doi:10.5194/acp-8-2933-2008, 2008.

Lance, S., Nenes, A., Mazzoleni, C., Dubey, M. K., Gates, H., Varutbangkul, V., Rissman, T. A., Murphy, S. M., Sorooshian, A., Flagan, R. C., Seinfeld, J. H., Feingold, G., and Jonsson, H. H.: Cloud condensation nuclei activity, closure, and droplet growth kinetics of Houston aerosol during the Gulf of Mexico Atmospheric Composition and Climate Study (GoMACCS), J. Geophys. Res., 114, D00F15, doi:10.1029/2008jd011699, 2009.

Medina, J., Nenes, A., Sotiropoulou, R. P., Cottrell, L. D., Ziemba, L. D., Beckman, P. J., and Griffin, R. J.: Cloud condensation nuclei closure during the International Consortium for Atmospheric Research on Transport and Transformation 2004 campaign: Effects of size-resolved composition, J. Geophys. Res., 112, D10S31, doi:10.1029/2006JD007588, 2007.

Mircea, M., Facchini, M. C., Decesari, S., Fuzzi, S., and Charlson, R. J.: The influence of the organic aerosol component on CCN supersaturation spectra for different aerosol types, Tellus B 54, 74-81, 2002.

Mircea, M., Facchini, M. C., Decesari, S., Cavalli, F., Emblico, L., Fuzzi, S., Vestin, A., Rissler, J., Swietlicki, E., Frank, G., Andreae, M. O., Maenhaut, W., Rudich, Y., and Artaxo, P.: Importance of the organic aerosol fraction for modeling aerosol hygroscopic growth and activation: a case study in the Amazon Basin, Atmos. Chem. Phys., 5, 3111-3126, doi:10.5194/acp-53111-2005, 2005.

Moffet, R. C., de Foy, B., Molina, L. T., Molina, M. J., and Prather, K. A.: Measurement of ambient aerosols in northern Mexico City by single particle mass spectrometry, Atmos. Chem. Phys., 8, 4499-4516, doi:10.5194/acp-8-4499-2008, 2008.

Petters, M. D., Prenni, A. J., Kreidenweis, S. M., DeMott, P. J., Matsunaga, A., Lim, Y. B., and Ziemann, P. J.: Chemical aging and the hydrophobic-hydrophilic conversion of carbonaceous aerosol, Geophys. Res. Lett., 33, L24806, doi:10.1029/2006GL027249, 2006.

Petters, M. D. and Kreidenweis, S. M.: A single parameter representation of hygroscopic growth and cloud condensation nucleus activity, Atmos. Chem. Phys., 7, 1961-1971, doi:10.5194/acp-71961-2007, 2007.

Pierce, J. R., Chen, K., and Adams, P. J.: Contribution of primary carbonaceous aerosol to cloud condensation nuclei: processes and uncertainties evaluated with a global aerosol microphysics model, Atmos. Chem. Phys., 7, 5447-5466, doi:10.5194/acp-75447-2007, 2007.

Quinn, P. K., Bates, T. S., Coffman, D. J., and Covert, D. S.: Influence of particle size and chemistry on the cloud nucleating properties of aerosols, Atmos. Chem. Phys., 8, 1029-1042, doi:10.5194/acp-8-1029-2008, 2008.

Riemer, N., West, M., Zaveri, R., and Easter, R.: Estimating black carbon aging time-scales with a particle resolved aerosol model, J. Aerosol Sci., 1, 143-158, 2010.

Rissler, J., Vestin, A., Swietlicki, E., Fisch, G., Zhou, J., Artaxo, P., and Andreae, M. O.: Size distribution and hygroscopic properties of aerosol particles from dry-season biomass burning in Amazonia, Atmos. Chem. Phys., 6, 471-491, doi:10.5194/acp6-471-2006, 2006.

Roberts, G., Mauger, G., Hadley, O., and Ramanathan, V.: North American and Asian aerosols over the eastern Pacific Ocean and their role in regulating cloud condensation nuclei, J. Geophys.
Res., 111, D13205, doi:10.1029/2005JD006661, 2006.

Roberts, G. C., Day, D. A., Russell, L. M., Dunlea, E. J., Jimenez, J. L., Tomlinson, J. M., Collins, D. R., Shinozuka, Y., and Clarke, A. D.: Characterization of particle cloud droplet activity and composition in the free troposphere and the boundary layer during INTEX-B, Atmos. Chem. Phys. Discuss., 10, 3499-3546, doi:10.5194/acpd-10-3499-2010, 2010.

Rose, D., Nowak, A., Achtert, P., Wiedensohler, A., Hu, M., Shao, M., Zhang, Y., Andreae, M. O., and Pöschl, U.: Cloud condensation nuclei in polluted air and biomass burning smoke near the mega-city Guangzhou, China - Part 1: Size-resolved measurements and implications for the modeling of aerosol particle hygroscopicity and CCN activity, Atmos. Chem. Phys., 10, 33653383, doi:10.5194/acp-10-3365-2010, 2010.

Shantz, N. C., Leaitch, W. R., Phinney, L., Mozurkewich, M., and Toom-Sauntry, D.: The effect of organic compounds on the growth rate of cloud droplets in marine and forest settings, Atmos. Chem. Phys., 8, 5869-5887, doi:10.5194/acp-8-5869-2008, 2008.

Sotiropoulou, R. P., Medina, J., and Nenes, A.: CCN predictions: Is theory sufficient for assessments of the indirect effect?, Geophys. Res. Lett., 33, L05816, doi:10.1029/2005GL025148, 2006.

Sotiropulou, R.-E. P., Nenes, A., Adams, P. J., and Seinfeld, J. H.: Cloud condensation nuclei prediction error from application of Köhler theory: Importance for the aerosol indirect effect, J. Geophys. Res., 112, D12202, doi:10.1029/2006JD007834, 2007.

Spencer, M. T., Shields, L. G., and Prather, K. A.: Simultaneous measurements of the effective density and chemical composition of ambient aerosol particles Environ. Sci. Technol., 41, 13031309, 2007.

Stroud, C., Nenes, A., Jimenez, J. L., DeCarlo, P., Huffman, J. A., Bruintjes, R., Nemitz, E., Delia, A. E., Toohey, D. W., Guenther, A. B., and Nandi, S.: Cloud activating properties of aerosol observed during CELTIC, J. Atmos. Sci., 64, 441-459, 2007.

Swietlicki, E., J. Zhou, O. H. Berg, B. G. Martinsson, G. Frank, S. Cederfeldt, U. Dusek, A. Berner, W. Birmili, A. Wiedensohler, Yuskiewicz, B., and Bower, K. N.: A closure study of sub-micrometer aerosol particle hygroscopic behaviour, Atmos. Res., 50, 205-240, 1999.

Twohy, C. H. and Anderson, J. R.: Droplet nuclei on nonprecipitating clouds: composition and size matter, Environ. Res. Lett., 3, 4, doi:10.1088/1748-9326/1083/1084/0045002, 2008.

Väkevä, M., Kulmala, M., Stratmann, F., and Hmeri, K.: Field measurements of hygroscopic properties and state of mixing of nucleation mode particles, Atmos. Chem. Phys., 2, 55-66, doi:10.5194/acp-2-55-2002, 2002.

Wang, J., Lee, Y.-N., Daum, P. H., Jayne, J., and Alexander, M. L.: Effects of aerosol organics on cloud condensation nucleus (CCN) concentration and first indirect aerosol effect, Atmos. Chem. Phys., 8, 6325-6339, doi:10.5194/acp-8-6325-2008, 2008.

Wang, J., Cubison, M. J., Aiken, A. C., Jimenez, J. L., and Collins, D. R.: The importance of aerosol mixing state and size-resolved composition on $\mathrm{CCN}$ concentration and the variation of the importance with atmospheric aging of aerosols, Atmos. Chem. Phys. Discuss., 10, 11751-11793, doi:10.5194/acpd-10-117512010, 2010.

Williams, B. J., Goldstein, A. H., Millet, D. B., Holzinger, R., Kreisberg, N. M., Hering, S. V., White, A. B., Worsnop, D. R., Allan, J. D., and Jimenez, J. L.: Chemical speciation of 
organic aerosol during the International Consortium for Atmospheric Research on Transport and Transformation 2004: Results from in situ measurements, J. Geophys. Res., 112, D10S26, doi:10.1029/2006JD007601, 2007.

Wilson, J., Cuvelier, C., and Raes, F.: A modeling study of global mixed aerosol fields, J. Geophys. Res., 106(D24), 34081-34108, 2001.
Zhang, Q., Stanier, C. O., Canagaratna, M. R., Jayne, J. T., Worsnop, D. R., Pandis, S. N., and Jimenez, J. L.: Insights into the Chemistry of New Particle Formation and Growth Events in Pittsburgh Based on Aerosol Mass Spectrometry, Environ. Sci. Technol., 38, 18, 4797-4809, doi:10.1021/es035417u, 2004. 